Description of a German circular spirit level

This content has been downloaded from IOPscience. Please scroll down to see the full text. 1919 Trans. Opt. Soc. 20157

(http://iopscience.iop.org/1475-4878/20/5/304)

View the table of contents for this issue, or go to the journal homepage for more

Download details:

IP Address: 131.111.164.128

This content was downloaded on 05/09/2015 at $16: 22$

Please note that terms and conditions apply. 


\title{
DESCRIP'TION OF A GERMAN CIRCULAR SPIRIT LEVEL
}

\author{
By JAMES W. FRENCH, B.Sc. \\ Read, i3th February, I9I9
}

Straight tubular spirit levels have the advantage that, when the level is heated, there can be no loss of the spirit, provided the temperature is not raised to such an extent as to increase the internal pressure unduly, as would be the case if the vapour bubble disappeared, in which case the tube might fracture. Spirit levels in which the spirit is contained in a metal holder and the bubble is viewed through a glass window suitably curved on the under side are not always free from this objection.

The following description of a circular spirit level taken from the compass of a Zeiss director may be of interest to the members of the Optical Society, as the design of level in question appears to be unaffected by considerable increases of temperature.

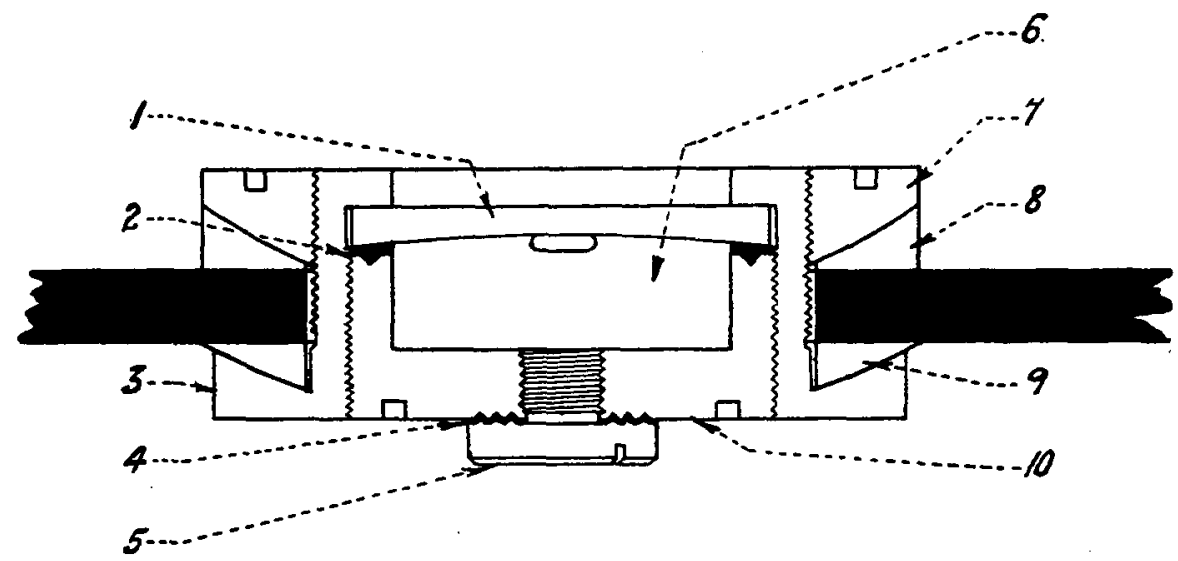

r. Winclow. Undersicle tine ground with ${ }_{5}$ min. emery. Radius of curvature $=26$ inches.

2. Lead loil Washer. 3. Bubble Cell Holder. t. Lead Foil Washor. 5. Screw. 6. Benzol. 7. Nut, spherical. S. Washer, spherical. y. Wisher, spherical. ro. Bubble cell.

Section of Zeiss Circular Level.

The diagram shows the general arrangement. The spherical washers (8) and (9) and the nut (7) are provided for the adjustment of the spirit level as a whole relatively to the compass. Rotation of the bubble cell holder (3) relatively to the compass is prevented during adjustment by a small key not shown in the diagram. The window ( 1 ) is inserted in the bubble cell holder (3) and is retained in position 
by the bubble cell (ro). Between the cell (ro) and the window there is provided a.lead foil washer.

Benzol is inserted into the chamber of the bubble cell through a hole in the base which is finally closed by means of a screw (5). Between the under face of the screw head and the face of the bubble cell there is provided a lead foil washer. When the bubble cell is screwed hard home, the lead is squeezed into a " $\mathrm{V}$ " groove in the bubble cell and similar corrugations are provided between the screw (5) and the lower face of the bubble cell. It would appear that the tightness is due to the use of these lead foil washers.

The metal used is of the same brass composition throughout, but the exposed parts were nickel-plated. The analysis of the brass is as follows:

$\begin{array}{ll}\text { Tin } & \text { Nil } \\ \text { Lead } & 3.508 \text { per cent. } \\ \text { Silicon iron } & 0.028 \quad, \\ \text { Manganese } & \text { Nil } \\ \text { Nickel } & \text { Nil } \\ \text { Copper } & 57.520 \text { per cent. } \\ \text { Zinc } & 38.974 \quad, \\ & \text { 100.030 },\end{array}$

The composition of the brass calls for no special remarks except that the purpose of the unusually large percentage of lead is presumably to improve the drawing or machining qualities.

The glass used for the window was of very ordinary quality, probably ordinary sheet glass. The upper surface did not appear to have been worked. The under surface was curved to a radius of $26^{\prime \prime}$. It was grey-ground, evidently with i5minute emery.

The lead foil washers were $\circ r^{\prime \prime}$ thick. The practical effect of the lead washer is to make a tight joint between the contiguous parts, due to the screwing up of the cell (10) or the screw (5) respectively.

As the level is heated the brass will, expand more than the glass window, which would become slack in its seating. The ideal construction is one in which the arrangement of the materials is such that, as the level is heated, the differential expansion of the materials will be such that there is no slackening at the various joints. The coefficients of expansion of the materials are in the following ratios:

$\begin{array}{ll}\text { Drawn brass } & 0.19 \\ \text { Plate glass } & 0.09 \\ \text { Lead } & 0.29 .\end{array}$

Compared with the other materials, the expansion of the glass is therefore negligible, and it will be seen that the lead has considerably greater expansion than the brass. But the thickness of the washer is only ${ }^{\circ} \mathrm{I}^{\prime \prime}$, whereas the width of the space into which the glass and lead fit is $0.07^{\prime \prime}$ : therefore in the design indicated there must be an actual slackening of the jnint at the glass as the temperature is raised. 
Notwithstanding this, a spirit level made to the same design has successfully withstood five temperature tests in which the temperature was raised to a maximum of $140^{\circ} \mathrm{F}$., which was maintained in each case for thirty minutes.

The tightness of the spirit level would appear to be due solely to the malleability of the lead and the tightness with which the various parts are screwed together.

By a suitable choice of the material of the bubble cell and of the holder, together with a slight modification of the design, it should be possible to ensure an increase of pressure on the lead foil washer as the temperature is raised.

The level was found to contain benzol. 'The choice of a suitable liquid would appear to be determined by its viscosity and coefficient of expansion. A very viscous liquid would not respond to changes of level with sufficient rapidity and a liquid of high expansion woult cause the bubble to disappear for a comparatively small increase of temperature and increase the pressure, tending to cause the escape of liquid.

It should be observed that the grey appearance of the ground glass will depend upon the refractive index of the spirit. A tube filled with ether will look greyer than when filled with benzol.

The expansions of various spirits are in the following ratios:

$\begin{array}{ll}\text { Benzol } & \mathrm{I} \cdot \mathrm{I} 76 \\ \text { Ethyl alcohol } & \mathrm{I} \cdot 0_{4} \mathrm{I} \\ \text { Ether } & \mathrm{I} \cdot 5 \mathrm{I} 3 \\ \text { Carbon disulphide } & \mathrm{I} \cdot \mathrm{I} 4 \mathrm{O}\end{array}$

It will be seen that, so far as expansion is concerned, benzol should give considerably better results than ether, that it is somewhat worse than ethyl alcohol, and about the same as carbon disulphide.

The viscosities of the various spirits are in the following ratios, the viscosities being measured at $20^{\circ} \mathrm{C}$.:

$\begin{array}{ll}\text { Benzol } & .006 \\ \text { Ethyl alcohol } & .012 \\ \text { Ether } & .002 \\ \text { Carbon disulphide } & .004\end{array}$

Whereas benzol is worse than alcohol as regards expansion, it is twice as good as alcohol as regards viscosity, that is, from the point of view of a bubble. It is worse than ether as regards viscosity but, as already stated, it is much better than ether as regards expansion. Benzol is worse than carbon disulphide as regards viscosity and, as stated before, about the same as regards expansion. It must be borne in mind, however, that a certain amount of viscosity in the liquid may be desirable, the amount depending upon the purpose for which the level is required. On the whole, therefore, it would appear in this particular case that the choice of benzol as a spirit level liquid is a good one. The spirit appeared to be $90 \%$ benzol. 